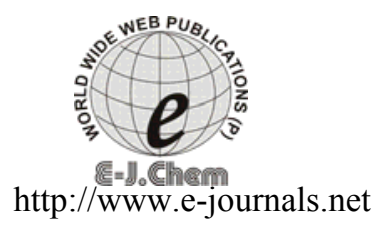

ISSN: 0973-4945; CODEN ECJHAO

E-Journal of Chemistry

2011, 8(S1), S203-S210

\title{
Construction of $\mathrm{Tb}^{3+}$ PVC-Membrane Electrode Based on $N, N^{\prime}$-Bis(pyrrolylmethylene)- 2-aminobenzylamine
}

\author{
HASSAN ALI ZAMANI ${ }^{\S *}$ ZYNAB RAFATI ${ }^{\S}$ and SORAIA MEGHDADI \\ ${ }^{\S}$ Department of Applied Chemistry, Quchan branch \\ Islamic Azad University, Quchan, Iran \\ Department of Chemistry, Isfahan University of Technology \\ Isfahan 84156-83111, Iran \\ haszamani@yahoo.com
}

Received 17 April 2011; Accepted 3 July 2011

\begin{abstract}
In this work, we report as new $\mathrm{Tb}^{3+}$-PVC membrane sensor based on $N, N^{\prime}$-bis(pyrrolylmethylene)- 2-aminobenzylamine (PMA) as a suitable ion carrier. Poly vinylchloride (PVC)-based membrane composed of PMA with oleic acid (OA) as anionic additives and acetophenone (AP) as plasticizing solvent mediators. The $\mathrm{Tb}^{3+}$ sensor exhibits a Nernstian slope of $19.7 \pm 0.4 \mathrm{mV}$ per decade over the concentration range of $1.0 \times 10^{-5}$ to $1.0 \times 10^{-2} \mathrm{M}$ and a detection limit of $4.6 \times 10^{-6} \mathrm{M}$ of $\mathrm{Tb}^{3+}$ ions. The potentiometric response of the sensor is independent of the solution $\mathrm{pH}$ in the range of 2.9-8.1. It has a very short response time, in the whole concentration range $(\sim 5 \mathrm{~s})$. The recommended sensor revealed comparatively good selectivity with respect to most alkali, alkaline earth, some transition and heavy metal ions. It was successfully employed as an indicator electrode in the potentiometric titration of $\mathrm{Tb}(\mathrm{III})$ ions with EDTA. The electrode was also employed for the determination of the fluoride ion in two mouth wash preparations and the determination of $\mathrm{Tb}^{3+}$ ions concentration in mixtures of three different ions.
\end{abstract}

Keywords: Sensor, Potentiometry, PVC membrane, Ion-selective electrode

\section{Introduction}

Terbium is classified as a rare earth element. Terbium is used to dope calcium fluoride, calcium tungstate and strontium molybdate, materials that are used in solid-state devices, and as a crystal stabilizer of fuel cells which operate at elevated temperatures, together with $\mathrm{ZrO}_{2}$. There are some instrumental methods for terbium analysis by inductively coupled plasma-atomic emission spectrometry (ICP-AES), ICP-MS, neutron activation analysis (NAA), 
$\mathrm{x}$-ray fluorescence, isotope dilution mass spectrometry and spectrophotometry. Although these techniques provide an accurate measurement in trace amount of elements, they destroyed the samples. In comparison, potentiometric ion selective sensors offer advantages of low cost, portability, selectivity and simple operatory. They also provide an analysis method without destruction of sample ${ }^{1-20}$. Recently, several greatly selective and sensitive polyvinyl chloride (PVC)-membrane ISEs for various metal ions have been reported ${ }^{21-35}$. Literature survey shows that four are some reports on selective determination of $\mathrm{Tb}(\mathrm{III})$ ions $^{36-38}$ in presence of other rare earth elements by electrochemical method. In this report we are going to introduce another terbium(III) PVC membrane electrode, based on $N, N$ '-bis(pyrrolylmethylene)- 2-aminobenzylamine (PMA) (Figure 1) as an excellent ionophore, for determination of $\mathrm{Tb}(\mathrm{III})$ with high selectivity, low detection limit and short response time.

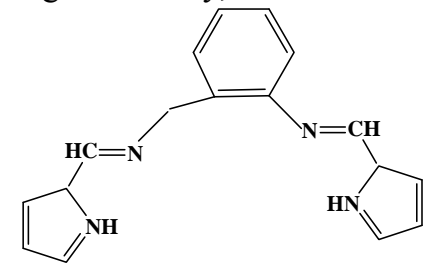

Figure 1. The PMA structure

\section{Experimental}

Reagent grade nitrobenzene (NB), dibutyl phthalate (DBP), benzyl acetate (BA), acetophenon (AP), oleic acid (OA), sodium tetraphenyl borate (NaTPB), tetrahydrofuran (THF) and high relative molecular weight PVC (all from Merck and Aldrich) were used as received. The $N, N$ '-bis(pyrrolylmethylene)-2-aminobenzylamin (PMA) was synthesized by a literature method $^{39}$. The nitrate and chloride salts of all cations used (all from Merck and Aldrich) were of the highest purity available and used without any further purification except for vacuum drying over $\mathrm{P}_{2} \mathrm{O}_{5}$. Doubly distilled de-ionized water was used throughout.

\section{Electrode preparation}

The required amounts of the membrane ingredients $(30 \mathrm{mg}$ powdered $\mathrm{PVC}$ and $58 \mathrm{mg}$ AP as plasticizer) were mixed and dissolved in $5 \mathrm{~mL}$ of THF. To this mixture, $10 \mathrm{mg}$ $\mathrm{OA}$ and $2 \mathrm{mg}$ ionophore PMA were added and the solution was mixed well. The resulting mixture was transferred into a glass dish of $2 \mathrm{~cm}$ in diameter. The THF content of the mixture was evaporated slowly, until an oily concentrated mixture was obtained. A pyrex tube (3-5 $\mathrm{mm}$ i.d.) was dipped into the mixture for about $10 \mathrm{~s}$, so that a transparent membrane of about $0.3 \mathrm{~mm}$ in thickness was formed ${ }^{18-22}$. Afterwards, the tube was removed from the solution kept at room temperature for $24 \mathrm{~h}$ and filled with an internal solution $\left(1.0 \times 10^{-3} \mathrm{M} \mathrm{TbCl}_{3}\right)$. The electrode was finally conditioned for $36 \mathrm{~h}$ by soaking in a $1.0 \times 10^{-3} \mathrm{M}$ solution of $\mathrm{TbCl}_{3}$. A silver/silver chloride coated wire was used as an internal reference electrode.

\section{The EMF measurements}

All emf measurements were carried out with the following assembly; $\mathrm{Ag}-\mathrm{AgCl} \mid 3 \mathrm{M}$ $\mathrm{KCl}$ |internal solution, $1.0 \times 10^{-3} \mathrm{M} \mathrm{TbCl} 3 \mid \mathrm{PVC}$ membrane|test solution| $\mid \mathrm{Hg}-\mathrm{Hg} 2 \mathrm{Cl} 2, \mathrm{KCl}$ (saturated). A Corning ion analyzer $250 \mathrm{pH} / \mathrm{mV}$ meter was used for the potential measurements at $25.0 \pm 0.1{ }^{\circ} \mathrm{C}$. The activities were calculated according to the Debye-Huckel procedure $^{40}$. 


\section{Results and Discussion}

\section{Potential response of the electrode}

The existence of four donating nitrogen atoms in the structure of PMA was expected to increase both the stability and selectivity of its complexes with alkali and alkaline earth metal ions, rather than transition and heavy metal ions. In primary experiments, in order to check the PMA suitability as an ionophore for different metal ions, PMA was used as a neutral ionophore to prepare a great deal of membrane electrodes for some metal ions. The potential responses of the membrane sensors based PMA toward other cations were studied. Except for $\mathrm{Tb}^{3+}$ ion, for all other cations, the slope of the corresponding potential $\mathrm{pM}^{\mathrm{n}+}$ plots is much lower than the expected Nernstian slopes of 59, 29.5 and $20 \mathrm{mV}$ decade $^{-1}$ for the univalent, bivalent and trivalent cations, respectively. Therefore, the ionophore (PMA) was selected as a suitable sensing material for $\mathrm{Tb}^{3+}$ ions in the PVC matrix.

\section{Effect of the membrane composition}

Some important features of the PVC membranes, such as the properties of the plasticizer, the plasticizer/PVC ratio, the nature and amount of ionophore and especially, the nature and amount of the additives used, are reported to significantly influence the sensitivity and selectivity of the ion-selective electrodes ${ }^{41-43}$. Thus, different aspects of the preparation of a $\mathrm{Tb}^{3+}$ - selective membrane based on PMA were optimized and the results are given in Table 1.

Table 1. Composition of membrane ingredients

\begin{tabular}{|c|c|c|c|c|c|c|}
\hline \multirow{2}{*}{$\begin{array}{c}\text { Membrane } \\
\text { No. }\end{array}$} & \multicolumn{4}{|c|}{ Composition, wt. $\%$} & \multirow{2}{*}{$\begin{array}{c}\text { Slope, } \\
\text { mV/decade }\end{array}$} & \multirow{2}{*}{$\begin{array}{l}\text { Concentration } \\
\text { range, } \mathrm{M}\end{array}$} \\
\hline & PVC & Plasticizer & Additive & $\mathrm{L}$ & & \\
\hline 1 & 30 & $\mathrm{NB}, 66$ & NaTPB,2 & 2 & $15.4 \pm 0.4$ & $1.0 \times 10^{-5}-1.0 \times 10^{-2}$ \\
\hline 2 & 30 & AP, 66 & NaTPB,2 & 2 & $13.9 \pm 0.3$ & $1.0 \times 10^{-5}-1.0 \times 10^{-2}$ \\
\hline 3 & 30 & BA, 66 & $\mathrm{NaTPB}, 2$ & 2 & $11.3 \pm 0.4$ & $1.0 \times 10^{-5}-1.0 \times 10^{-2}$ \\
\hline 4 & 30 & DBP, 66 & NaTPB,2 & 2 & $10.5 \pm 0.5$ & $1.0 \times 10^{-5}-1.0 \times 10^{-2}$ \\
\hline 5 & 30 & AP, 58 & $\mathrm{OA}, 10$ & 2 & $19.7 \pm 0.4$ & $1.0 \times 10^{-5}-1.0 \times 10^{-2}$ \\
\hline 6 & 30 & $\mathrm{NB}, 63$ & OA,5 & 2 & $17.5 \pm 0.6$ & $1.0 \times 10^{-5}-1.0 \times 10^{-2}$ \\
\hline 7 & 30 & $\mathrm{NB}, 56$ & NaTPB,2; OA,10 & 2 & $16.3 \pm 0.5$ & $1.0 \times 10^{-5}-1.0 \times 10^{-3}$ \\
\hline 8 & 30 & $\mathrm{NB}, 57$ & NaTPB,2; OA, 10 & 1 & $18.6 \pm 0.5$ & $1.0 \times 10^{-5}-1.0 \times 10^{-3}$ \\
\hline 9 & 30 & $\mathrm{NB}, 50$ & NaTPB,2; OA, 15 & 3 & $17.7 \pm 0.3$ & $1.0 \times 10^{-5}-1.0 \times 10^{-2}$ \\
\hline
\end{tabular}

Since the nature of plasticizer influences the dielectric constant of the membrane phase, the mobility of the ionophore molecules and the state of ligand $d^{41-43}$, it was expected to play a key role in determining the selectivity, working concentration range and response time of the membrane electrode. Obviously from Table 1, among the four tried plasticizers, AP offers the best sensitivity. It can be seen that the ionophore amount increase up to a value of $2 \%$, in the presence of $58 \%$ of plasticizer (AP), results in the best sensitivity (no. 5). The maximum slope of $19.7 \pm 0.4 \mathrm{mV}$ per decade of $\mathrm{Tb}$ (III) concentration was observed for the membrane no. 5 with $2 \%$ of PMA. It is well known that the presence of lipophilic anions in cationselective membranes based on neutral carriers not only diminishes the ohmic resistance and enhances the response behavior and selectivity but also, in cases where the extraction capability is poor, it increases the sensitivity of the membrane electrodes ${ }^{43-45}$. However, the membranes with a composition of 30\% PVC, 2\% PMA, 10\% OA and 58\% AP (no. 5) illustrate a Nernstian potential response. 


\section{Calibration curve}

The emf response of the PVC membrane at varying concentrations of terbium ions (Figure 2) indicates a rectilinear range from $1.0 \times 10^{-5}$ to $1.0 \times 10^{-2} \mathrm{M}$. The slope of the calibration curve was $19.7 \pm 0.4 \mathrm{mV}$ per decade of $\mathrm{Tb}^{3+}$ ions activity. The detection limit, as determined from the intersection of the two extrapolated segments of the calibration curve, was $4.6 \times 10^{-6} \mathrm{M}$.

\section{pH Effect}

The $\mathrm{pH}$ dependence of the membrane electrode was tested for the $\mathrm{pH}$ values (concentrated $\mathrm{NaOH}$ or $\mathrm{HCl}$ was used for the $\mathrm{pH}$ adjustment) from 2.0 up to 10.0 at certain $\mathrm{Tb}^{3+}$ ion concentration $\left(1.0 \times 10^{-3} \mathrm{M}\right)$ and the result is depicted in Figure 3. As can be seen, the potential remains fairly constant in the $\mathrm{pH}$ range of $2.9-8.1$. Beyond this range, a gradual change in the potential was detected. The observed potential drift at the higher $\mathrm{pH}$ values could be due to the formation of some hydroxyl complexes of $\mathrm{Tb}^{3+}$ and insoluble terbium hydroxide, that in both cases, the concentration of free $\mathrm{Tb}$ (III) reduces in the solution. At the lower $\mathrm{pH}$ values than 2.9 , the potentials increase, indicating that the membrane sensor responds to hydrogen ions.

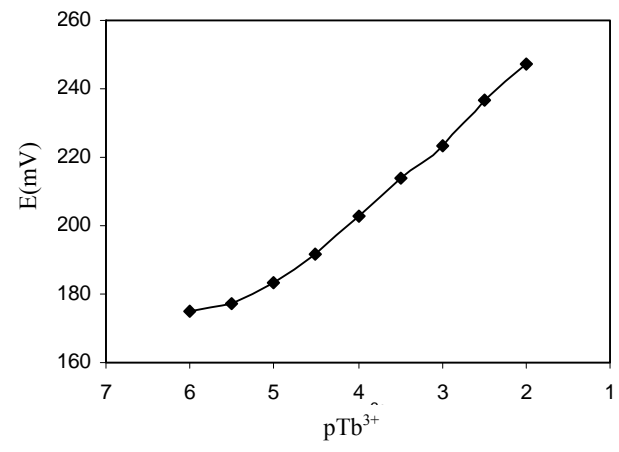

Figure 2. The calibration curve of the terbium electrode, based on PMA

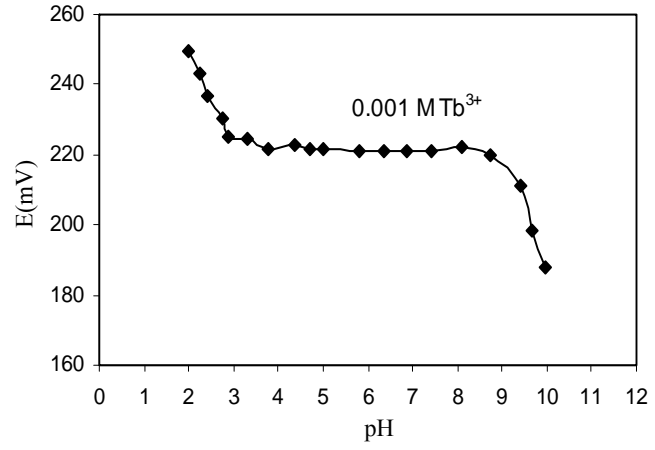

Figure 3. The $\mathrm{pH}$ effect of the test solution on the potential response of the terbium sensor

\section{Dynamic response time}

For analytical applications, dynamic response time is very important for any sensor. The dynamic response time of the membrane was measured at various concentrations $\left(1.0 \times 10^{-5}\right.$ to $\left.1.0 \times 10^{-2} \mathrm{M}\right)$ of the test solutions and results are illustrated in Figure 4. As can be seen, in the whole concentration range the electrode reaches its equilibrium response, very fast $(\sim 5 \mathrm{~s})$.

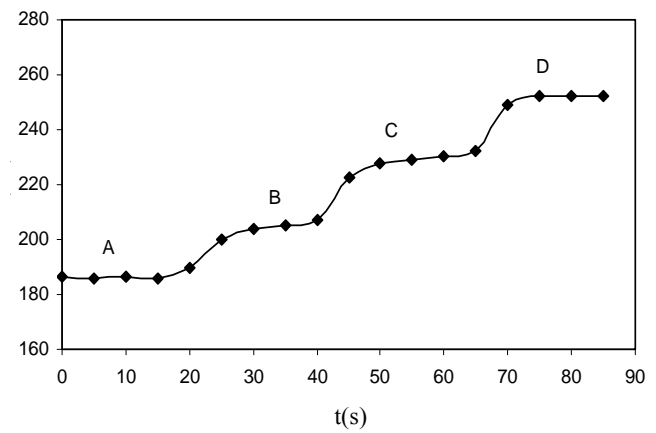

Figure 4. The dynamic response time of the terbium electrode for step changes in the $\mathrm{Tb}^{3+}$ concentration: A) $1.0 \times 10^{-5} \mathrm{M}$, B) $1.0 \times 10^{-4} \mathrm{M}$, C) $1.0 \times 10^{-3} \mathrm{M}$, D) $1.0 \times 10^{-2} \mathrm{M}$ 


\section{Sensor selectivity}

Selectivity coefficients describing the membrane preference towards an interfering ion was determined by the match potential method (MPM) ${ }^{46,47}$. According to the MPM method, a specified activity (concentration) of primary ions (A) is added to a reference solution and the potential is measured. In a separate experiment, interfering ions (B) are successively added to an identical reference solution until the measured potential matches that obtained before the primary ion addition. The matched potential method selectivity coefficient, $K^{\mathrm{MPM}}$, is then given by the resulting primary ion to interfering ion activity (concentration) ratio, $K^{\mathrm{MPM}}=\mathrm{a}_{\mathrm{A}} / \mathrm{a}_{\mathrm{B}}$. The resulted potentiometric selectivity coefficients values are summarized in Table 2. The data given in Table 2, show the selectivity coefficients of the proposed $\mathrm{Tb}^{3+}$ membrane sensor were $4.1 \times 10^{-3}$ or smaller and revealed that the proposed $\mathrm{Tb}^{3+}$ membrane sensor is highly selective with respect to most of transition and heavy metal ions. The surprisingly high selectivity of the membrane electrode for terbium ions over other cations used, most probably arises from the strong tendency of the carrier molecules for terbium ions.

Table 2. Selectivity coefficients of various interfering ions

\begin{tabular}{cc}
\hline Interfering ion $(\mathrm{B})$ & Selectivity coefficient $\left(\mathrm{K}_{\mathrm{Tb}, \mathrm{B}}\right)$ \\
\hline $\mathrm{Ho}^{3+}$ & $4.1 \times 10^{-3}$ \\
$\mathrm{Sm}^{3+}$ & $6.5 \times 10^{-4}$ \\
$\mathrm{Pr}^{3+}$ & $6.4 \times 10^{-4}$ \\
$\mathrm{Eu}^{3+}$ & $7.8 \times 10^{-4}$ \\
$\mathrm{Lu}^{3+}$ & $2.1 \times 10^{-3}$ \\
$\mathrm{Nd}^{3+}$ & $2.7 \times 10^{-3}$ \\
$\mathrm{Tm}^{3+}$ & $3.2 \times 10^{-3}$ \\
$\mathrm{Er}^{3+}$ & $7.5 \times 10^{-4}$ \\
$\mathrm{Gd}^{3+}$ & $7.8 \times 10^{-4}$ \\
$\mathrm{Cr}^{3+}$ & $6.5 \times 10^{-4}$ \\
$\mathrm{Fe}^{3+}$ & $7.2 \times 10^{-4}$ \\
$\mathrm{~Pb}^{2+}$ & $7.3 \times 10^{-4}$ \\
$\mathrm{Hg}^{2+}$ & $8.4 \times 10^{-4}$ \\
$\mathrm{Cd}^{2+}$ & $7.2 \times 10^{-4}$ \\
$\mathrm{Cu}^{2+}$ & $8.5 \times 10^{-4}$ \\
$\mathrm{Ca}^{2+}$ & $6.8 \times 10^{-4}$ \\
$\mathrm{Mg}^{2+}$ & $5.9 \times 10^{-4}$ \\
$\mathrm{Na}^{+}$ & $4.7 \times 10^{-4}$ \\
\hline
\end{tabular}

\section{Analytical applications}

$\mathrm{The} \mathrm{Tb}(\mathrm{III})$ sensor was successfully used as an indicator electrode in the titration of $20.0 \mathrm{~mL}$ of a $1.0 \times 10^{-4} \mathrm{~Tb}^{3+}$ solution with a $1.0 \times 10^{-2} \mathrm{M}$ EDTA. The resulting titration curve is given in Figure 5, demonstrating that the amount of $\mathrm{Tb}(\mathrm{III})$ ion in the solution can be determined with the electrode. 


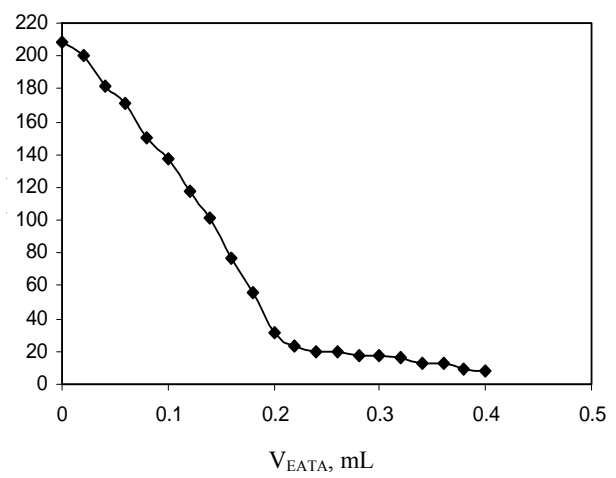

Figure 5. Potential titration curve of $20.0 \mathrm{~mL}$ from a $1.0 \times 10^{-4} \mathrm{M} \mathrm{Tb}^{3+}$ solution with $1.0 \times 10^{-2} \mathrm{M}$ of EDTA

The proposed sensor was also successfully applied to the determination of $\mathrm{Tb}^{3+}$ ions in mixtures of three different ions and the results are summarized in Table 3 . The corresponding results in Table 3 reveal that the recovery of $\mathrm{Tb}^{3+}$ ions in all mixtures is acceptable.

Table 3. Determination of $\mathrm{Tb}^{3+}$ ions in mixtures of different ions

\begin{tabular}{ccc}
\hline S No. & \multicolumn{1}{c}{ Composition } & $\begin{array}{c}\text { Observed } \\
\text { content, } \mathrm{M}\end{array}$ \\
\hline 1 & $0.00010 \mathrm{M} \mathrm{Tb}\left(\mathrm{NO}_{3}\right)_{3}+0.001 \mathrm{M} \mathrm{Ho}\left(\mathrm{NO}_{3}\right)_{3}+0.001 \mathrm{M} \mathrm{Eu}\left(\mathrm{NO}_{3}\right)_{3}$ & 0.000102 \\
2 & $0.00010 \mathrm{M} \mathrm{Tb}\left(\mathrm{NO}_{3}\right)_{3}+0.001 \mathrm{M} \mathrm{Pb}\left(\mathrm{NO}_{3}\right)_{2}+0.001 \mathrm{M} \mathrm{Co}\left(\mathrm{NO}_{3}\right)_{2}$ & 0.000105 \\
3 & $0.00010 \mathrm{M} \mathrm{Tb}\left(\mathrm{NO}_{3}\right)_{3}+0.001 \mathrm{M} \mathrm{NaNO}{ }_{3}+0.001 \mathrm{M} \mathrm{Ca}\left(\mathrm{NO}_{3}\right)_{2}$ & 0.000098 \\
4 & $0.00010 \mathrm{M} \mathrm{Tb}\left(\mathrm{NO}_{3}\right)_{3}+0.001 \mathrm{M} \mathrm{Cr}\left(\mathrm{NO}_{3}\right)_{3}+0.001 \mathrm{M} \mathrm{Fe}\left(\mathrm{NO}_{3}\right)_{3}$ & 0.000096 \\
5 & $0.00010 \mathrm{M} \mathrm{Tb}\left(\mathrm{NO}_{3}\right)_{3}+0.001 \mathrm{M} \mathrm{Tm}\left(\mathrm{NO}_{3}\right)_{3}+0.001 \mathrm{M} \mathrm{Lu}\left(\mathrm{NO}_{3}\right)_{3}$ & 0.000093 \\
6 & $0.00010 \mathrm{M} \mathrm{Tb}\left(\mathrm{NO}_{3}\right)_{3}+0.001 \mathrm{M} \mathrm{Sm}\left(\mathrm{NO}_{3}\right)_{3}+0.001 \mathrm{M} \mathrm{Gd}\left(\mathrm{NO}_{3}\right)_{3}$ & 0.000103 \\
7 & $0.00010 \mathrm{M} \mathrm{Tb}\left(\mathrm{NO}_{3}\right)_{3}+0.001 \mathrm{M} \mathrm{Er}\left(\mathrm{NO}_{3}\right)_{3}+0.001 \mathrm{M} \mathrm{Pr}\left(\mathrm{NO}_{3}\right)_{3}$ & 0.000097 \\
8 & $0.00010 \mathrm{M} \mathrm{Tb}\left(\mathrm{NO}_{3}\right)_{3}+0.001 \mathrm{M} \mathrm{Ni}\left(\mathrm{NO}_{3}\right)_{2}+0.001 \mathrm{M} \mathrm{KNO}_{3}$ & 0.000098 \\
\hline
\end{tabular}

Because of high selectivity and low detection limit of the developed $\mathrm{Tb}^{3+}$ sensor (membrane no. 5), it was also applied for the determination of fluoride ions in two mouth wash samples. $1.0 \mathrm{~g}$ of each sample was taken and diluted with distilled water in a $100 \mathrm{~mL}$ flask and titrated with a $\mathrm{Tb}^{3+}$ solution $\left(1.0 \times 10^{-3} \mathrm{M}\right)$. The associated results, after triplicate measurements, are summarized in Table 4 . As it is seen, there is a satisfactory agreement among the declared fluoride content, the determined values by the sensor.

Table 4. Fluoride ions determination in mouth wash solutions

\begin{tabular}{ccc}
\hline Sample & Labeled, ppm & Found ISE ${ }^{\mathrm{a}}, \mathrm{ppm}$ \\
\hline $\begin{array}{c}\text { Sodium fluoride mouth wash solution } \\
\text { (Aquafresh, Brentford, U.K.) }\end{array}$ & 1350 & $(1378 \pm 21)$ \\
$\begin{array}{c}\text { Sodium fluoride mouth wash solution } \\
\text { (Eurodont, DuroDont GmbH) }\end{array}$ & 1450 & $(1484 \pm 17)$ \\
\hline
\end{tabular}

\section{Conclusion}

a: Suggested $T b^{3+}$ sensor, $b$. Results are based on three measurements

The use of the $N, N$ '-bis(pyrrolylmethylene)- 2-aminobenzylamine (PMA) with AP as plasticizer shows the best response characteristics with Nernstian behavior across the concentration range 
of $1.0 \times 10^{-5}-1.0 \times 10^{-1} \mathrm{M} \mathrm{Tb}^{3+}$ with the slope of $19.7 \pm 0.4 \mathrm{mV}$ per decade of activity. The sensors were found to work well in the $\mathrm{pH}$ range of 2.9-8.1 with response time of less than $5 \mathrm{~s}$ and showed reproducible and stable potentiometric signals. Its selectivity towards the terbium ions was not influenced by the presence of the common alkali, alkaline earth, or transition and heavy metal ions, since the interference of these substances was low. For the accuracy of the electrode performance, it was used for the determination of the fluoride ion in mouth wash solutions and the monitoring of $\mathrm{Tb}^{3+}$ ions in mixtures of different ions solution.

\section{Acknowledgment}

The authors gratefully acknowledge the financial support of this research proposal, provided by the Research Council of the Quchan Islamic Azad University.

\section{References}

1. Zamani H A, Feizyzadeh B, Faridbod F and Ganjali M R, Sensor Lett., 2011, 9, 1767.

2. Mahajan R K, Kaur I and Kumar M, Sens Actuators B, 2003, 91, 26.

3. Zamani H A, Rohani M, Mohammadhosseini M, Ganjali M R, Faridbod F and Meghdadi S, Sensor Lett., 2011, 9, 1745.

4. Ganjali M R, Norouzi P, Adib M and Ahmadalinezhad A, Anal Lett., 2006, 39, 1075.

5. Zamani H A, Anal Lett., 2009, 42, 615.

6. Zamani H A, Abedi MR and Ganjali M R, J Chil Chem Soc., 2009, 54, 186.

7. Jain A K, Singh A K, Mehtab S and Saxena P, Anal Chim Acta, 2005, 551, 45.

8. Zamani H A, Masrournia M, Rostame-Faroge M, Ganjali M R and Behmadi H, Sensor Lett., 2008, 6, 759.

9. Zamani H A, Ganjali M R, Norouzi P and Adib M, Mater Sci Eng C, 2008, 28, 157.

10. Ganjali M R, Rasoolipour S, Rezapour M, Norouzi P, Amirnasr M and Meghdadi S, Sens Actuators B, 2006, 119, 89.

11. Zamani H A, Mohammadhossieni M, Nekoei M and Ganjali M R, Sensor Lett., $2010,8,303$.

12. Naddaf E and Zamani H A, Anal Lett., 2009, 42, 2838.

13. Zamani H A, Ganjali M R and Seifi N, Collect Czech Chem Commun., 2007, 72, 1189.

14. Zamani H A, Anal Lett., 2008, 41, 1850.

15. Ganjali M R, Rasoolipour S, Rezapour M, Norouzi P, Amirnasr M and Meghdadi S, $J$ Braz Chem Soc., 2006, 17, 1211-1216.

16. Zamani H A, Ganjali M R, Behmadi H and Behnajady M A, Mater Sci Eng C, 2009, 29, 1535.

17. Zamani H A, Masrournia M, Sahebnasagh S and Ganjali M R, Anal Lett., 2009, 42, 555.

18. Liu L, Wang L, Yin H, Li Y and He X, Anal Lett., 2006, 39, 879.

19. Zamani H A, Ganjali M R, Norouzi P and Meghdadi S, Anal Lett., 2008, 41, 902.

20. Nekoei M, Zamani H A and Mohammadhossieni M, Anal Lett., 2009, 42, 284.

21. Mohammadhossieni M, Zamani H A and Nekoei M, Anal Lett., 2009, 42, 298.

22. Luo E P, Chai Y Q and Yuan R, Anal Lett., 2007, 40, 369.

23. Zamani H A, Rajabzadeh G and Ganjali M R, Sensor Lett., 2009, 7, 114.

24. Abedi M R and Zamani H A, Anal Lett., 2008, 41, 2251.

25. Abedi M R, Zamani H A, Ganjali M R and Norouzi P, Sensor Lett., 2007, 5, 516.

26. Zamani M A, Ganjali M R, Norouzi P and Meghdadi S, J Appl Electrochem., 2007, 37, 853-859.

27. Behmadi H, Zamani H A, Ganjali M R and Norouzi P, Electrochim. Acta., 2007, 53, 1870. 
28. Zamani H A, Zabihi M S, Rohani M, Zangeneh-Asadabadi A, Ganjali M R, Faridbod F and Meghdadi S, Mater Sci Eng C, 2011, 31, 409.

29. Zamani H A, Arvinfar A, Rahimi F, Imani A, Ganjali M R and Meghdadi S, Mater Sci Eng C, 2011, 31, 307.

30. Zamani H A, Nekoei M, Mohammadhosseini M and Ganjali M R, Mater Sci Eng C, 2010, 30, 480.

31. Zamani H A, Rohani M, Zangeneh-Asadabadi A, Zabihi M S, Ganjali M R and Salavati-Niasari M, Mater Sci Eng C, 2010, 30, 917.

32. Masrournia M, Zamani H A, Mirrashid H A, Ganjali M R and Faridbod F, Mater Sci Eng C, 2011, 31, 574.

33. Zamani H A, Imani A, Arvinfar A, Rahimi F, Ganjali M R, Faridbod F and Meghdadi S, Mater Sci Eng C, 2011, 31, 588.

34. Zamani H A, Feizyzadeh B, Faridbod F and Ganjali M R, Mater Sci Eng C, 2011, 31, 1379.

35. Zamani H A, Ganjali M R and Faridbod F, J Serb Chem Soc., 2011, 76, 1295.

36. Zamani H A, Ganjali M R, Norouzi P, Tadjarodi A and Shahsavani E, Mater Sci Eng C, 2008, 28, 1489.

37. Zamani H A, Rajabzadeh G and Ganjali M R, J Braz Chem Soc., 2006, 17, 1297.

38. Ganjali M R, Ghesmi A, Hosseini M, Pourjavid M R, Rezapour M, Shamsipur M and Salavati-Niasari M, Sens Actuators B, 2005, 105, 334-339.

39. Amirnasr M, Schenk K J, Gorji A, and Vafazadeh R, Polyhedron, 2001, 20, 695-702.

40. Kamata S, Bhale A, Fukunaga Y and Murata A, Anal Chem., 1988, 60, 2464.

41. Rosatzin T, Bakker E, Suzuki Y and Simon W, Anal Chim Acta, 1993, 280, 197.

42. Zamani H A, Rajabzadeh G, Firouz A and Ganjali M R, J Anal Chem., 2007, 62, 1080.

43. Ammann E, Pretsch E, Simon W, Lindner E, Bezegh A and Pungor E, Anal Chim Acta, 1985, 171, 119.

44. Zamani H A, Rajabzadeh G, Masrornia M, Dejbord A, Ganjali M R and Seifi N, Desalination, 2009, 249, 560-565.

45. Bakker E, Bühlmann P and Pretsch E, Chem Rev., 1997, 97, 3083-3132.

46. Umezawa Y, Buhlmann P, Umezawa K, Tohda K and Amemiya S, Pure Appl Chem., 2000, 72, 1851-2082.

47. Zamani H A, Hamed-Mosavian M T, Aminzadeh E, Ganjali M R, Ghaemy M, Behmadi H and Faridbod F, Desalination, 2010, 250, 56. 


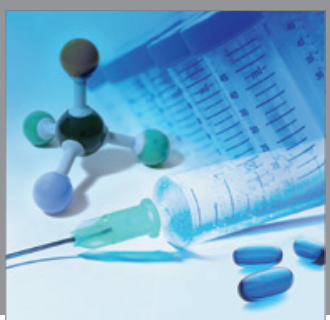

International Journal of

Medicinal Chemistry

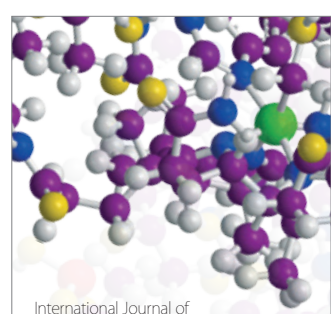

Carbohydrate Chemistry

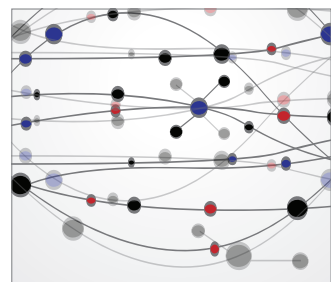

The Scientific World Journal
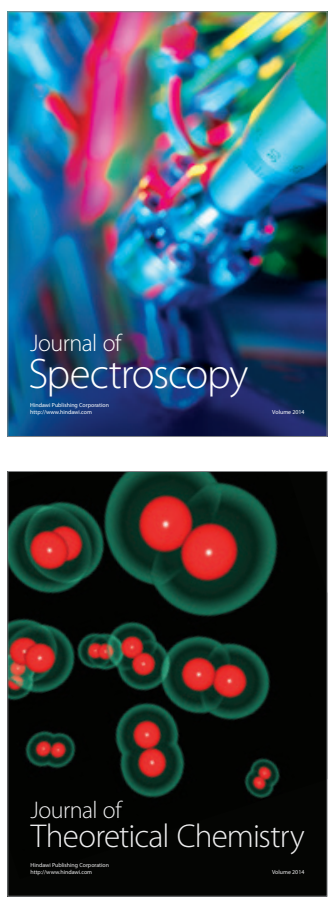
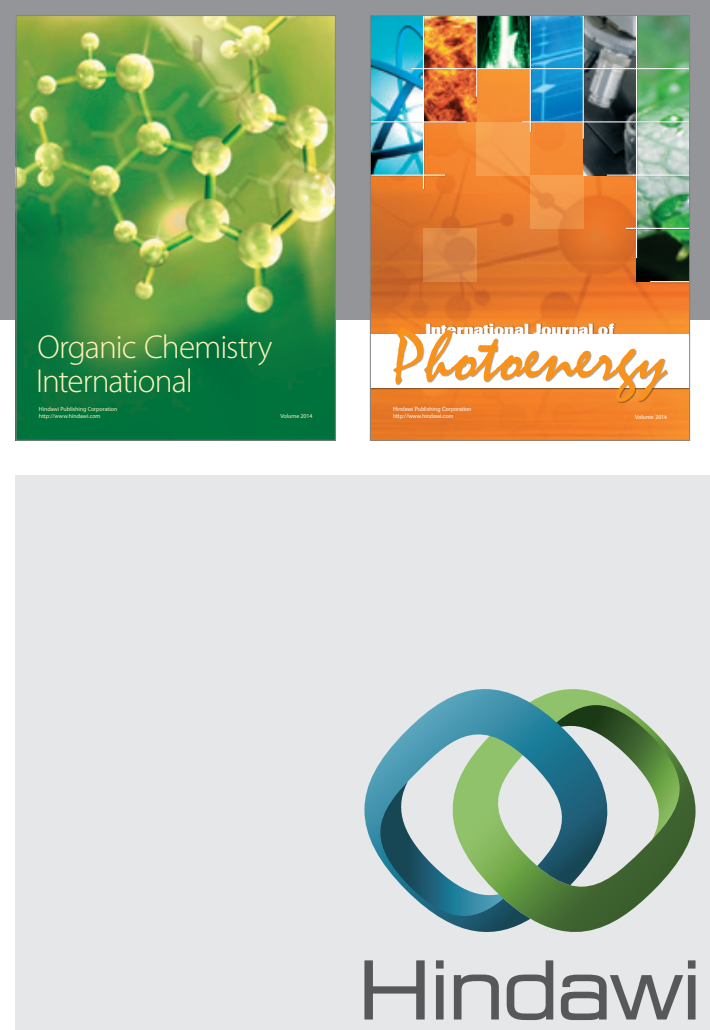

Submit your manuscripts at

http://www.hindawi.com
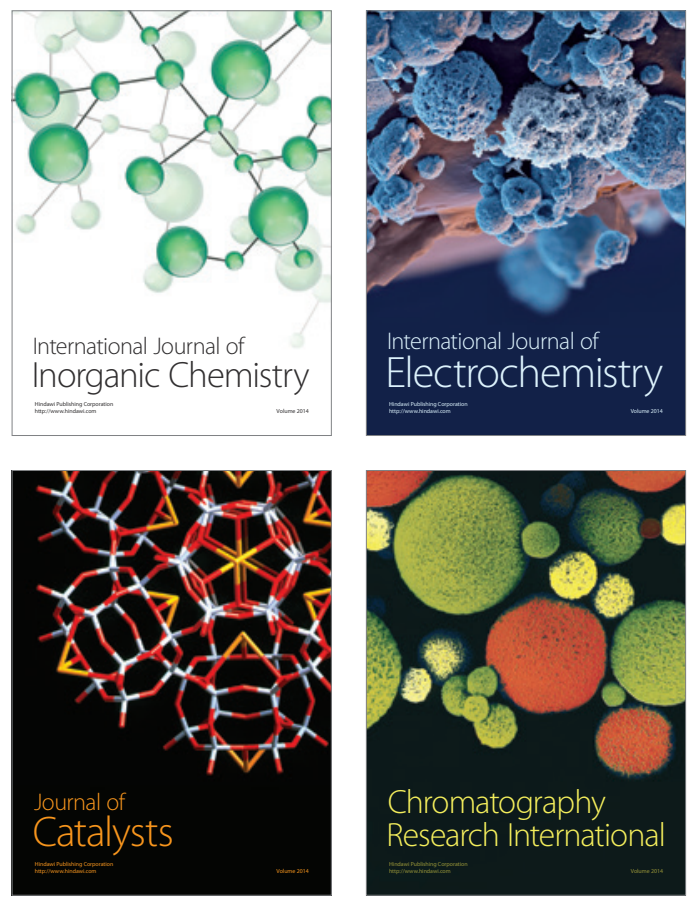
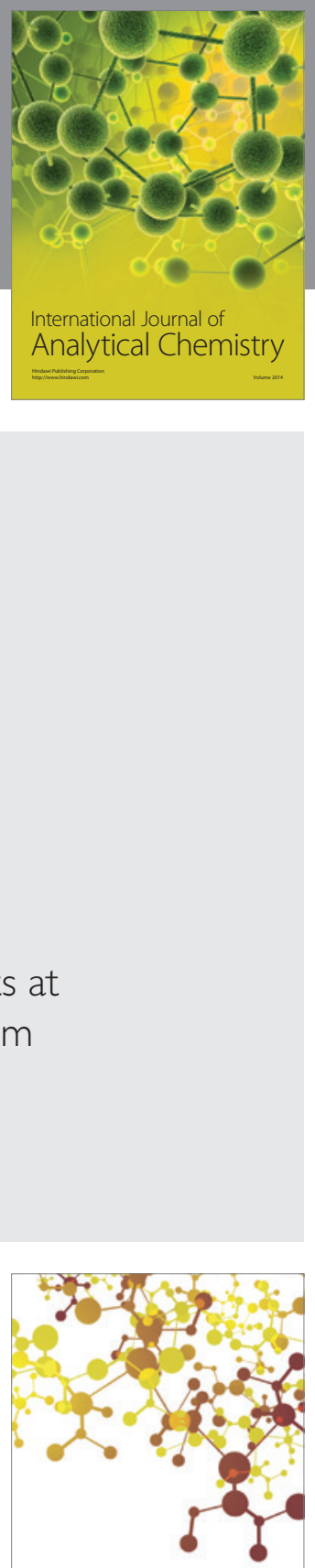

Journal of

Applied Chemistry
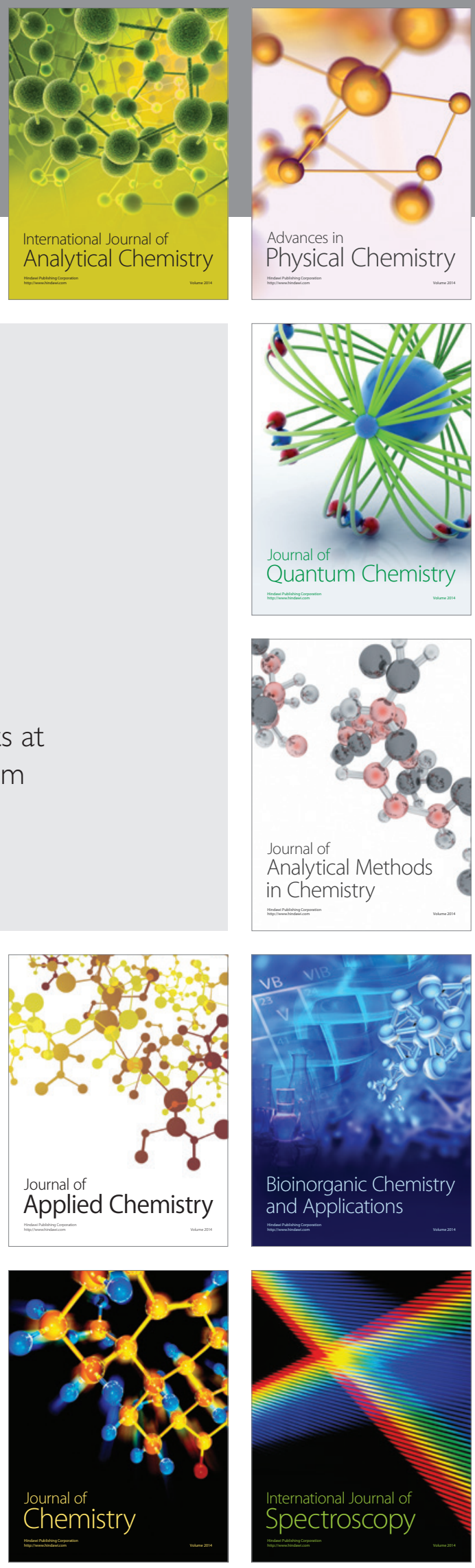